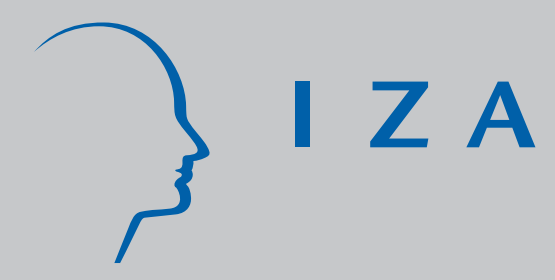

IZA DP No. 1881

Preferences, Gender Segregation and Affirmative Action

Peter J. Sloane

Suzanne Grazier

Richard J. J ones

December 2005 


\title{
Preferences, Gender Segregation and Affirmative Action
}

\author{
Peter J. Sloane \\ University of Wales at Swansea \\ and IZA Bonn \\ Suzanne Grazier \\ University of Wales at Swansea \\ Richard J. Jones \\ University of Wales at Swansea
}

Discussion Paper No. 1881

December 2005

\author{
IZA \\ P.O. Box 7240 \\ 53072 Bonn \\ Germany \\ Phone: +49-228-3894-0 \\ Fax: +49-228-3894-180 \\ Email: iza@iza.org
}

Any opinions expressed here are those of the author(s) and not those of the institute. Research disseminated by IZA may include views on policy, but the institute itself takes no institutional policy positions.

The Institute for the Study of Labor (IZA) in Bonn is a local and virtual international research center and a place of communication between science, politics and business. IZA is an independent nonprofit company supported by Deutsche Post World Net. The center is associated with the University of Bonn and offers a stimulating research environment through its research networks, research support, and visitors and doctoral programs. IZA engages in (i) original and internationally competitive research in all fields of labor economics, (ii) development of policy concepts, and (iii) dissemination of research results and concepts to the interested public.

IZA Discussion Papers often represent preliminary work and are circulated to encourage discussion. Citation of such a paper should account for its provisional character. A revised version may be available directly from the author. 
IZA Discussion Paper No. 1881

December 2005

\section{ABSTRACT}

\section{Preferences, Gender Segregation and Affirmative Action*}

In the UK concern has been expressed over the degree of gender occupational segregation. Though there are no general provisions for affirmative action, it does apply in limited areas and pro-active measures have been suggested. In this paper we focus on gender differences in work preferences in relation to job satisfaction, risk aversion and self employment, and question the rationale for affirmative action.

JEL Classification: J0, J2, K2

Keywords: occupational segregation, job satisfaction, risk aversion, gender, affirmative action

Corresponding author:

Peter J. Sloane

Department of Economics

University of Wales, Swansea

James Callaghan Building

Singleton Park

Swansea SA2 8PP

United Kingdom

Email: p.j.sloane@swansea.ac.uk

\footnotetext{
* An earlier version of this paper was presented at the 65th Annual Meeting of the Academy of Management, Honolulu, Workshop on Diversity, Affirmative Action and Human Resource Management, August 5-10, 2005.
} 


\section{Introduction}

Within Britain the Equal Opportunities Commission (EOC) has shown increasing concern over the persistence of gender occupational segregation and launched a General Formal Investigation (GFI) into the issue under section 58 (1) of the Sex Discrimination Act in 2003. The context for this was the fact that the number of women in the British labour force had increased substantially over a long period with the greatest increase in labour force participation found amongst married women. The composition of the labour force had also changed with a decline in male intensive industries, such as parts of manufacturing and an increase in services, where many women have traditionally been employed. Yet, a substantial amount of occupational segregation persists. The EOC Equal Pay Task Force (2001) had already reported that occupational segregation was one of the three main contributors to the gender pay gap. Horizontal segregation crowded women into female dominated occupations and industries, depressing pay there, while vertical segregation limited the career development of women, excluding them from promoted posts with higher rates of pay. $^{1}$

A significant feature of prevailing employment patterns is the extent to which females are found in jobs which utilise skills complementary or identical to those required in household duties, such as childcare, food preparation or cleaning. Often female jobs involve light rather than heavy physical demands (which in the latter case are in decline), or require a high degree of manual dexterity (e.g. electronic engineering), or entail a high degree of contact with customers (e.g. the distributive trades). An important issue is whether gender segregation is a consequence of genuine

\footnotetext{
${ }^{1}$ For further evidence on this see Kidd and Goninon (2000) and Belfield (2005).
} 
occupational choice (different tastes for particular types of work on the part of men and women) or constraints upon choice though stereotyped offers of education, training and employment, limited availability of child-care facilities and constraints due to employer discrimination.

In Free to Choose (2003) based on the GFI the EOC suggested that the case for change rested on increased choice, increased opportunity and increased productivity. Barriers to change were seen as an education system which fails to support entry into non-traditional areas of employment, an apprenticeship and vocational training system which fails to support atypical recruits, a lack of co-ordinated action on the part of employers and a lack of appropriate national strategies. Amongst its proposals were targets with monitoring and evaluation for measuring progress. ${ }^{2}$ No consideration is given, however, to the possibility that men and women may have different preferences for particular types of work. Further, reducing gender segregation will only make a contribution to the performance of the economy if this enables individuals to be allocated to jobs where they are most productive. The EOC implicitly assumes that the optimal degree of gender segregation is lower than its current level. However, it is not possible to be precise about what level of gender segregation would be optimal in the absence of full knowledge of the work preferences of men and women. ${ }^{3}$ There may also be constraints on the job search behaviour of married women which are

\footnotetext{
${ }^{2}$ Whether this amounts to affirmative action is a moot point. Holzer and Neumark (2000) suggest that 'in principle at least affirmative action can be distinguished from other anti-discrimination measures by requiring pro-active steps (hence the phrase "affirmative") to erase differences between women and men....... in contrast to laws that only prevent employers from taking steps that disadvantage minorities in the labour market, such as refusing to hire them' (p. 484). They go on to suggest, however, that a working definition is difficult to construct because the definition is fuzzy, covers different spheres, the policy may operate at a number of levels, and it may cover different labour market activities.

${ }^{3}$ Holzer and Neumark (2000) is a very comprehensive survey of affirmative action, but fails to consider the possibility that gender segregation may be caused by different preferences for types of work on the part of men and women.
} 
more severe than those relating to married men, as illustrated by differences in journey to work patterns. There may also be different preferences or constraints with respect to hours of work. Bryan (2005), using WERS 98 data, finds large differences in the hours of women in the same workplaces, and in comparable jobs, according to whether or not they have young children. There is also some evidence that workers sort themselves into establishments working longer or shorter hours according to their individual preferences.

It is well known that, on average, males are more risk taking than women (Scotchmer, 2005). Datta Gupta et al. (2005) using experimental data show that when given a choice between the riskier option of a tournament or piece rates men choose a tournament significantly more often than women. Women are influenced mainly by their degree of risk aversion, but men are not. Brown and Taylor (2005) use detailed questions on investments in risky assets in the 1995 BHPS to examine the influence of risk preference on human capital formation and consequently wage growth. Males who are more likely than women to invest in risky assets such as shares and unit trusts are more likely to invest in human capital and experience more rapid wage growth. Ekelund et al. (1995) examine the effect of risk aversion on an individual's probability of being self employed, by using psychometric data from a large, population-based cohort of Firms in 1996. Men are less risk averse than women and this makes them significantly more likely to become self employed than women. There is in addition evidence that the self-employed are more subject to excessive optimism than employeed individuals, but women are less subject to this than men (Arabsheibani et al., 2000). 
Pay differences are also exacerbated by incomplete employee wage information. A study of eleven countries, including the UK revealed that incomplete information on what each firm pays led workers to receive on average about 30 to 35 per cent less than they otherwise could have earned. Furthermore, women suffer more from incomplete information than men. (see Polachek and Xiang, 2005)

In this paper we attempt to contribute to this question by considering three aspects of occupational choice which may explain at least part of occupational segregation. First, we consider the relationship between job satisfaction and aspects of work including gender segregation. Second, we consider the possibility that there are gender and family differences in aversion to types of work where accident risks are greater than elsewhere, that lead men to choose riskier jobs than women. Third, we examine the extent to which men and women become self-employed and their choice of particular types of self employment. First, however, we summarise the legal environment and record some facts relating to the degree of gender segregation in Britain. 


\section{The Legal Framework}

The 1975 Sex Discrimination Act prohibited discrimination with respect to hiring, opportunities for promotion, transfer and training and dismissal procedures on the basis of sex or marriage. That is the Act legislation offers protection to married persons of either sex, to single men and women separately, but not to single persons as a group. The discrimination provisions relate to two forms of discrimination direct and indirect. The latter occurs where a requirement or condition is applied to a number of either gender, but is such that the proportion of one gender that can comply with it is considerably smaller than that of the other gender (e.g. a height requirement).

Over time these equality rules have been extended, usually as a result of European Union legal decisions. Thus, in 1990 the European Court of Justice (ECJ) held that refusal to employ a woman because she was pregnant was unlawful. In 1986 the ECJ had held that equality must also apply to retirement ages for men and women, the statutory retirement ages in the UK being 60 for a woman and 65 for a man.

There is no provision in general for affirmative action in the above legislation. However, positive action in relation to the provision of training opportunities is permissible where there have been fewer or no members of one race or sex, in particular work in the previous twelve months. An exception is Northern Ireland, where with respect to religion there is provision for both affirmative action and contract compliance dating from 1984. The affirmative action provisions require the estimation of the expected composition of an organisation's workforce based on 
information regarding the religious composition of the geographical catchment area or labour market sector from which employees are drawn.

Affirmative action has, however, been introduced in Britain in two specific areas. First, in an attempt to increase the proportion of women in Parliament, the Labour Party adopted all women short-lists between 1993 and 1996. However, following a legal challenge in 1998 this policy was judged unlawful under the Sex Discrimination Act 1975. Subsequently, the Government introduced the Sex Discrimination (Election Candidates) Act 2002, which allows political parties to use positive measures to reduce inequality in the numbers of men and women elected to the House of Commons, the Scottish Parliament, the Welsh Assembly, the Northern Ireland Assembly, the European Parliament and local government elections. ${ }^{4}$ Positive measures permitted include training and mentoring, twinning and zapping ${ }^{5}$, and quotas (i.e. all women short-lists). In the 2005 General Election the imposition of a female candidate in a safe Labour constituency, Blaenau Gwent in the Welsh Valleys, caused local resentment. A Labour Party member of the Welsh Assembly, Peter Law, stood as an Independent in opposition to the female official Labour Candidate. He won the seat with a swing from Labour of $48.9 \%$. As a result he was expelled from the Party together with others, who had assisted in his election campaign.

A second example of affirmative action concerns University admissions. The Government has become increasingly concerned about the under-representation of

\footnotetext{
${ }^{4}$ In May 2005 the proportion of women in the House of Commons was 19.8\%, in the Northern Ireland Assembly 13\%, and in the European Parliament 24.4\%. Yet in the Scottish Parliament the figure was 39.5\%, in the Welsh Assembly 50\%.

${ }^{5}$ Twinning means pairing constituencies and putting men in some and women in others. Zapping applies where a list electoral system is used and the parties alternate male and female candidates on the list.
} 
certain groups in higher education. The participation of young people from Social Class V is significantly lower than from Social Classes I and II with young people living in the most advantaged $20 \%$ of areas five to six times more likely to enter higher education than those living in the least advantaged $20 \%$ of areas. The most significant factor in the social class division in HE participation is differential attainment in the schooling system. While around $40 \%$ of 18 year olds from higher socio-economic groups gain two or more A levels, the minimum requirement for entry into a degree programme, only $19 \%$ of those from lower social backgrounds do so. This is linked to entry into private schools, so universities are also set targets for increasing the proportion of students from state schools. Under the Higher Education Act 2004 HE institutions will be able to vary fees for full-time undergraduates up to a limit of $£ 3,000$ per annum. As a quid pro quo an Office for Fair Access (OFFA) has been set up to safeguard fair access to higher education for under-represented groups. In order to charge tuition fees above the standard level institutions are required to submit an Access Agreement spelling out how they will promote fair access in particular for students from low income groups. This shows that the Government is not averse to affirmative action where it believes circumstances warrant it. 


\section{The Facts}

First of all it is important to consider what is happening to occupational segregation over time. In order to establish this we compare the 1991 and 2001 Censuses of Population as these have the most substantial coverage of individuals in employment. A Census of people and households is conducted every ten years, with the latest one in April 2001. It is the only survey which provides a detailed picture of the entire population.

In order to compare changes over time we need a single index to measure the extent of segregation. We utilise two measures that have been widely used in the literature. The Duncan and Duncan Index of Dissimilarity and the Karmel and Maclachlan Index ${ }^{6}$

A measure which is commonly used is the Duncan and Duncan (1955) Index of Dissimilarity (ID). This index is a measure of the ABSOLUTE differences in the percentage distribution of males and females employed across occupations, namely

$\mathrm{ID}_{\mathrm{t}}=\frac{1}{2} \sum_{i=1}^{n}\left|f_{i t}-m_{i t}\right|$

where $f_{i t}$ and $m_{i t}$ are percentages of males and females employed in occupation $i$ at time $t$ respectively, and $i=1,2 \ldots, n$ represent the occupational categories. As relative numbers in each occupational category will vary a weighting scheme can be applied to the index, $S_{t}$ to obtain a weighted index of occupational segregation.

\footnotetext{
${ }^{6}$ There are alternative measures to these. See, for instance, Elliott(2005) who employs Theil's H, which focuses on the evenness dimension of segregation.
} 
$S_{t}$ takes values between zero (no segregation) and 100 (total segregation). It can be interpreted as representing the percentage of males or females who would have to change occupations for the gender distributions to become identical in the sense that they all reflect the shares of men and women in the total labour force.

However, ID is unsatisfactory in relation to the occupational invariance criterion and more recently the Karmel and Maclachlan (1988) index (IP) has been used to measure occupational segregation. This is given by

$$
\begin{gathered}
I P_{t}=\left(\frac{1}{T}\right) \sum\left|M_{i t}-a\left(M_{i t}+F_{i t}\right)\right| \\
\quad \text { or }\left(\frac{1}{T} \sum\left|(1-a) M_{i t}-a F_{i t}\right|\right.
\end{gathered}
$$

Where $T$ represents total employment, $a$ the male share of total employment, $M$, the number of males in occupation $i$ and $F_{i}$ the number of females in occupation $i$. This meets the criteria of organisational equivalence, size invariance, gender symmetry and the weak version of the principle of transfers. The composition effect is both composition invariant and occupations invariant.

In Table 1 we report the results of estimating occupational segregation in 1991 and 2001 on the basis of a socio-economic groups, using the two latest Censuses of Population. ${ }^{7}$ Both the Index of Dissimilarity and the Karmel and Maclachlan Index suggest that segregation for all ages is higher in Wales than in England or Scotland, but it has declined in all three countries over the decade by between 4 and 5 per cent in Britain as a whole but rather faster in Wales and slower in Scotland. In 2001 over

\footnotetext{
${ }^{7}$ The estimate of occupational segregation is not invariant to the level of occupational disaggregation. Thus using a two digit occupational breakdown raises the ID measure of segregation to 49 per cent, while the figure for the three digit breakdown is 47 per cent.
} 
one-third of men or women would have to change occupation for the gender distributions to become identical in the sense that they all reflect the shares of men and women in the total labour force. The biggest reduction in segregation in the decade has occurred for the youngest age group 16-19 years, which is consistent with the evidence that the degree of segregation is declining. Further, segregation remains highest in the older age groups 50 to 64 years according to the Index of Dissimilarity and in the age group 50-59 according to the Karmel and Maclachlan Index. It remains the case, however, that any reduction in gender segregation is a slow process.

Table 1: Measures of Occupational Segregation Using the 1991 and 2001 Censuses.

Census of Population: Index of Dissimilarity between Occupations - Great Britain

\begin{tabular}{|l|lrrrrrr|}
\hline & $\begin{array}{l}\text { All } \\
\text { Ages }\end{array}$ & $\mathbf{1 6 - 1 9}$ & $\mathbf{2 0 - 2 9}$ & $\mathbf{3 0 - 4 4}$ & $\mathbf{4 5 - 6 4}$ & & $\mathbf{6 5 +}$ \\
\hline $\mathbf{1 9 9 1}$ & 38.37 & 40.96 & 35.97 & 39.36 & 42.15 & & 35.70 \\
\hline & $\begin{array}{l}\text { All } \\
\text { Ages }\end{array}$ & $\mathbf{1 6 - 1 9}$ & $\mathbf{2 0 - 2 9}$ & $\mathbf{3 0 - 4 9}$ & $\mathbf{5 0 - 5 9}$ & $\mathbf{6 0 - 6 4}$ & $\mathbf{6 5 - 7 4}$ \\
\hline $\mathbf{2 0 0 1}$ & 36.56 & 34.85 & 33.50 & 38.28 & 41.24 & 40.92 & 38.21 \\
\hline
\end{tabular}

Census of Population : The Karmel and Maclachlan Index - Great Britain

\begin{tabular}{|l|lrrrrrr|}
\hline & $\begin{array}{l}\text { All } \\
\text { Ages }\end{array}$ & $\mathbf{1 6 - 1 9}$ & $\mathbf{2 0 - 2 9}$ & $\mathbf{3 0 - 4 4}$ & $\mathbf{4 5 - 6 4}$ & & $\mathbf{6 5 +}$ \\
\hline $\mathbf{1 9 9 1}$ & 0.189 & 0.205 & 0.179 & 0.194 & 0.202 & & 0.163 \\
\hline & All & & & & & & \\
& Ages & $\mathbf{1 6 - 1 9}$ & $\mathbf{2 0 - 2 9}$ & $\mathbf{3 0 - 4 9}$ & $\mathbf{5 0 - 5 9}$ & $\mathbf{6 0 - 6 4}$ & $\mathbf{6 5 - 7 4}$ \\
\hline $\mathbf{2 0 0 1}$ & 0.182 & 0.174 & 0.167 & 0.190 & 0.205 & 0.187 & 0.180 \\
\hline
\end{tabular}




\section{Occupational Segregation and Job Satisfaction}

\section{(a) WERS Analysis}

The data used in our regression analysis are drawn from the 1998 Workplace Employee Relations Survey (WERS), which is a national survey of British workplaces with 10 or more employees, in all industry sectors except agriculture and coalmining (Department of Trade and Industry, 1999) ${ }^{8}$. The survey is the fourth, and most recent, survey in the Workplace Industrial Relations Survey (WIRS) Series; previous studies having taken place in 1980, 1984 and 1990.

From each workplace an interview is conducted with the senior person at the workplace with day-to-day responsibility for industrial relations, employee relations or personnel matters and with the most senior representative of the trade union with the largest number of members at the workplace, or with the most senior employee representative who sits on a workplace-level consultative committee. Moreover, a sample of individuals from these workplaces was questioned on a range of topics. One of the main advantages of the survey is that it allows the linking of responses from particular workplaces thus enabling us to examine work and workplace characteristics. There are 2,191 workplaces in the data and 28,215 associated employees.

Workers are asked a number of questions concerning different aspects of job satisfaction, namely:

1. how satisfied are you with the amount of influence you have over your job?

2. how satisfied are you with the amount of pay you receive?

\footnotetext{
${ }^{8}$ Department of Trade and Industry (1999) "Workshop Employee Relations Survey: Cross-Section, 1999” (computer file), $4^{\text {th }}$ edition. Colchester: The UK Data Archive (distributor).
} 
3. how satisfied are you with the sense of achievement you get from your work?

4. how satisfied are you with the respect you get from supervisors/line managers?

5. do you feel loyal to your organisation?

6. are you proud to tell people who you work for?

Workers are asked to rate their satisfaction (questions 1 to 4 ) on a five point scale with 1 representing very dissatisfied; 3 neither satisfied nor dissatisfied and 5 being very satisfied. For questions 5 and 6 workers use another five point scale with 1 representing strong disagreement, 3 neither agree nor disagree and 5 strong agreement. The distribution of responses to these questions is shown in table 2 . Consistent with previous studies, average satisfaction with each of the aspects is higher for females than for males. 
Table 2a: Aspects of Job Satisfaction - Males

\begin{tabular}{|c|c|c|c|c|c|c|c|}
\hline & $\begin{array}{c}\text { Very } \\
\text { dissatisfied }\end{array}$ & Dissatisfied & $\begin{array}{c}\text { Neither } \\
\text { satisfied } \\
\text { nor } \\
\text { dissatisfied } \\
\end{array}$ & Satisfied & $\begin{array}{c}\text { Very } \\
\text { satisfied }\end{array}$ & $\mathbf{n}$ & Mean \\
\hline \multicolumn{8}{|c|}{ How satisfied are you with the... } \\
\hline $\begin{array}{l}\text { amount of } \\
\text { influence you } \\
\text { have over your } \\
\text { job? }\end{array}$ & $4.03 \%$ & $13.45 \%$ & $24.57 \%$ & $45.68 \%$ & $12.28 \%$ & 13,637 & 3.49 \\
\hline $\begin{array}{l}\text { amount of pay } \\
\text { you receive? }\end{array}$ & $14.65 \%$ & $29.11 \%$ & $23.41 \%$ & $29.5 \%$ & $3.33 \%$ & 13,709 & 2.78 \\
\hline $\begin{array}{l}\text { achievement } \\
\text { you get from } \\
\text { your work? }\end{array}$ & $5.3 \%$ & $11.33 \%$ & $22.4 \%$ & $46.85 \%$ & $14.11 \%$ & 13,658 & 3.53 \\
\hline $\begin{array}{l}\text { respect you get } \\
\text { from } \\
\text { supervisors/line } \\
\text { managers? }\end{array}$ & $10.14 \%$ & $13.5 \%$ & $21.92 \%$ & $42.19 \%$ & $12.25 \%$ & 13,634 & 3.33 \\
\hline & $\begin{array}{l}\text { Strongly } \\
\text { disagree }\end{array}$ & Disagree & $\begin{array}{c}\text { Neither } \\
\text { agree } \\
\text { nor } \\
\text { disagree }\end{array}$ & Agree & $\begin{array}{c}\text { Strongly } \\
\text { agree }\end{array}$ & $\mathbf{n}$ & Mean \\
\hline $\begin{array}{l}\text { Do you feel } \\
\text { loyal to your } \\
\text { organisation? }\end{array}$ & $4.53 \%$ & $8.94 \%$ & $23.44 \%$ & $46.59 \%$ & $16.5 \%$ & 13,585 & 3.62 \\
\hline $\begin{array}{l}\text { Are you proud } \\
\text { to tell people } \\
\text { who you work } \\
\text { for? }\end{array}$ & $5.5 \%$ & $8.74 \%$ & $31.85 \%$ & $36.91 \%$ & $17.01 \%$ & 13,606 & 3.51 \\
\hline
\end{tabular}


Table 2b: Aspects of Job Satisfaction - Females

\begin{tabular}{|c|c|c|c|c|c|c|c|}
\hline & $\begin{array}{c}\text { Very } \\
\text { dissatisfied }\end{array}$ & Dissatisfied & $\begin{array}{c}\text { Neither } \\
\text { satisfied } \\
\text { nor } \\
\text { dissatisfied }\end{array}$ & Satisfied & $\begin{array}{c}\text { Very } \\
\text { satisfied }\end{array}$ & $\mathbf{n}$ & Mean \\
\hline \multicolumn{8}{|c|}{ How satisfied are you with the... } \\
\hline $\begin{array}{l}\text { amount of } \\
\text { influence you } \\
\text { have over your } \\
\text { job? }\end{array}$ & $2.35 \%$ & $11.67 \%$ & $25.91 \%$ & $48.88 \%$ & $11.18 \%$ & 14,013 & 3.55 \\
\hline $\begin{array}{l}\text { amount of pay } \\
\text { you receive? }\end{array}$ & $10.35 \%$ & $27.42 \%$ & $23.64 \%$ & $34.97 \%$ & $3.62 \%$ & 14,180 & 2.94 \\
\hline $\begin{array}{l}\text { achievement } \\
\text { you get from } \\
\text { your work? }\end{array}$ & $3.57 \%$ & $9.79 \%$ & $19.51 \%$ & $51.13 \%$ & $16 \%$ & 14,161 & 3.66 \\
\hline \multirow[t]{2}{*}{$\begin{array}{l}\text { respect you get } \\
\text { from } \\
\text { supervisors/line } \\
\text { managers? }\end{array}$} & $6.33 \%$ & $11.47 \%$ & $19.61 \%$ & $46.29 \%$ & $16.3 \%$ & 14,120 & 3.55 \\
\hline & $\begin{array}{l}\text { Strongly } \\
\text { disagree }\end{array}$ & Disagree & $\begin{array}{l}\text { Neither } \\
\text { agree } \\
\text { nor } \\
\text { disagree }\end{array}$ & Agree & $\begin{array}{c}\text { Strongly } \\
\text { agree }\end{array}$ & $\mathbf{n}$ & Mean \\
\hline $\begin{array}{l}\text { Do you feel } \\
\text { loyal to you } \\
\text { organisation? }\end{array}$ & $1.87 \%$ & $5.83 \%$ & $22.82 \%$ & $53.7 \%$ & $15.78 \%$ & 13,985 & 3.76 \\
\hline $\begin{array}{l}\text { Are you proud } \\
\text { to tell people } \\
\text { who you work } \\
\text { for? }\end{array}$ & $2.69 \%$ & $6.94 \%$ & $31.83 \%$ & $42.68 \%$ & $15.87 \%$ & 13,982 & 3.62 \\
\hline
\end{tabular}

We examine these responses further by grouping workers according to whether the work the individual does is done almost exclusively by men, mainly by men, equally by men and women, mainly by women or almost exclusively by women as defined by the individual respondents (Table 3).

Women who work in jobs that are mainly or almost exclusively done by women are more satisfied with the influence they have on their job compared to other women. Similarly they are more satisfied with the respect they get from line/managers, and 
feel more loyal to their organisation and have greater pride in telling people who they work for. In contrast, women who work in jobs that are mainly or almost exclusively done by men are more satisfied with their pay (though insignificantly so) and with the sense of achievement they get from their work.

We extend the analysis using a multivariate analysis. The categorical nature of dependent variable means that an ordered response model is appropriate. The model is based on assumption that satisfaction is described by underlying latent variable $S_{i}^{*}$ such that

$S_{i j}^{*}=X \beta_{1}+Z \beta_{2}+\varepsilon_{i j}$.

Where $\mathrm{X}$ is a vector of individual characteristics; $\mathrm{Z}$ a vector of workplace characteristics and $\beta_{1}$ and $\beta_{2}$ are the coefficient vectors associated with these characteristics. We observe $S_{\mathrm{ij}}=\mathrm{r}$ if $\gamma_{r-1} \leq S_{i j}^{*} \leq \gamma_{\mathrm{r}}$ with $\gamma_{0}=-\infty$ and $\gamma_{\mathrm{r}}=\infty$. Thus the probability that alternative $\mathrm{r}$ is chosen is the probability that the latent variable $S_{i}^{*}$ is between two boundaries $\gamma_{r-1}$ and $\gamma_{r}$. Assuming that the error term is independently and identically distributed following a standard normal distribution, this gives us the ordered probit model. A further complication arises because the data used in the analysis is multi-level and thus the error term can be written as,

$\varepsilon_{i j}=\varphi_{i j}+\theta_{j}$

where $\varphi_{i j}$ represents the part of the error term that varies independently across individuals both within and between establishments and $\theta_{j}$ measures the part that varies across establishments but which is constant for workers within establishments. This assumes that there are unobservable factors determining satisfaction that are common to workers within establishments and others that vary randomly across all 
workers. Thus the appropriate estimation framework is the ordered probit model with random effects. The results for females, derived using this framework, are shown in table 4.

Table 3: Aspects of Job Satisfaction by Job Gender Mix

\begin{tabular}{|l|c|c|c|c|c|}
\hline MALES & \multicolumn{4}{|c|}{ Job done... } \\
\hline & $\begin{array}{c}\text { Almost } \\
\text { exclusively } \\
\text { by men }\end{array}$ & $\begin{array}{c}\text { Mainly } \\
\text { by men }\end{array}$ & Equally & $\begin{array}{c}\text { Mainly } \\
\text { by } \\
\text { women }\end{array}$ & $\begin{array}{c}\text { Almost } \\
\text { exclusively by } \\
\text { women }\end{array}$ \\
\hline $\begin{array}{l}\text { How satisfied are you with } \\
\text { the amount of influence you } \\
\text { have over your job? }\end{array}$ & 3.48 & 3.48 & 3.53 & 3.28 & 3.87 \\
\hline $\begin{array}{l}\text { How satisfied are you with } \\
\text { the amount of pay you } \\
\text { receive? }\end{array}$ & 2.71 & 2.81 & 2.82 & 2.67 & 2.93 \\
\hline $\begin{array}{l}\text { How satisfied are you with } \\
\text { the sense of achievement } \\
\text { you get from your work? }\end{array}$ & 3.54 & 3.54 & 3.55 & 3.29 & 3.53 \\
\hline $\begin{array}{l}\text { How satisfied are you with } \\
\text { the respect you get from } \\
\text { supervisors/line managers? }\end{array}$ & 3.23 & 3.29 & 3.46 & 3.30 & 3.93 \\
\hline $\begin{array}{l}\text { Do you feel loyal to you } \\
\text { organisation? }\end{array}$ & 3.53 & 3.62 & 3.70 & 3.50 & 3.64 \\
\hline $\begin{array}{l}\text { Are you proud to tell } \\
\text { people who you work for? }\end{array}$ & 3.41 & 3.53 & 3.59 & 3.40 & 3.53 \\
\hline
\end{tabular}

\begin{tabular}{|l|c|c|c|c|c|}
\hline FEMALES & \multicolumn{5}{|c|}{ Job done... } \\
\hline $\begin{array}{l}\text { Almost } \\
\text { exclusively } \\
\text { by men }\end{array}$ & $\begin{array}{c}\text { Mainly } \\
\text { by men }\end{array}$ & Equally & $\begin{array}{c}\text { Mainly } \\
\text { by } \\
\text { women }\end{array}$ & $\begin{array}{c}\text { Almost } \\
\text { exclusively by } \\
\text { women }\end{array}$ \\
\hline $\begin{array}{l}\text { How satisfied are you with } \\
\text { the amount of influence you } \\
\text { have over your job? }\end{array}$ & 3.43 & 3.48 & 3.59 & 3.51 & 3.61 \\
\hline $\begin{array}{l}\text { How satisfied are you with } \\
\text { the amount of pay you } \\
\text { receive? }\end{array}$ & 3 & 2.92 & 3.01 & 2.91 & 2.90 \\
\hline $\begin{array}{l}\text { How satisfied are you with } \\
\text { the sense of achievement } \\
\text { you get from your work? }\end{array}$ & 3.91 & 3.51 & 3.66 & 3.65 & 3.74 \\
\hline $\begin{array}{l}\text { How satisfied are you with } \\
\text { the respect you get from } \\
\text { supervisors/line managers? }\end{array}$ & 3.35 & 3.37 & 3.57 & 3.54 & 3.59 \\
\hline $\begin{array}{l}\text { Do you feel loyal to you } \\
\text { organisation? }\end{array}$ & 3.62 & 3.66 & 3.76 & 3.75 & 3.82 \\
\hline $\begin{array}{l}\text { Are you proud to tell } \\
\text { people who you work } \\
\text { for? }\end{array}$ & 3.59 & 3.57 & 3.61 & 3.61 & 3.70 \\
\hline
\end{tabular}


Table 4: Determinants of Domains of Job Satisfaction - Females

\begin{tabular}{|c|c|c|c|c|c|c|}
\hline & $\begin{array}{l}\text { Satisfaction } \\
\text { with } \\
\text { influence }\end{array}$ & $\begin{array}{l}\text { Satisfaction } \\
\text { with pay }\end{array}$ & $\begin{array}{l}\text { Satisfaction } \\
\text { with sense } \\
\text { of } \\
\text { achievement }\end{array}$ & $\begin{array}{l}\text { Satisfaction } \\
\text { with } \\
\text { respect }\end{array}$ & Loyalty & Pride \\
\hline $\begin{array}{l}\text { Job done } \\
\text { mainly by } \\
\text { men }\end{array}$ & $\begin{array}{l}-0.034 \\
(0.109)\end{array}$ & $\begin{array}{l}-0.381 \\
(1.234)\end{array}$ & $\begin{array}{l}-0.403 \\
(1.278)\end{array}$ & $\begin{array}{l}0.205 \\
(0.669)\end{array}$ & $\begin{array}{l}0.304 \\
(0.971)\end{array}$ & $\begin{array}{l}0.153 \\
(0.486)\end{array}$ \\
\hline $\begin{array}{l}\text { Job done } \\
\text { equally by } \\
\text { men and } \\
\text { women }\end{array}$ & $\begin{array}{l}0.128 \\
(0.418)\end{array}$ & $\begin{array}{l}-0.149 \\
(0.487)\end{array}$ & $\begin{array}{l}-0.277 \\
(0.887)\end{array}$ & $\begin{array}{l}0.390 \\
(1.288)\end{array}$ & $\begin{array}{l}0.405 \\
(1.306)\end{array}$ & $\begin{array}{l}0.218 \\
(0.699)\end{array}$ \\
\hline $\begin{array}{l}\text { Job done } \\
\text { mainly by } \\
\text { women }\end{array}$ & $\begin{array}{l}0.011 \\
(0.036)\end{array}$ & $\begin{array}{l}-0.226 \\
(0.740)\end{array}$ & $\begin{array}{l}-0.343 \\
(1.099)\end{array}$ & $\begin{array}{l}0.316 \\
(1.045)\end{array}$ & $\begin{array}{l}0.353 \\
(1.137)\end{array}$ & $\begin{array}{l}0.156 \\
(0.499)\end{array}$ \\
\hline $\begin{array}{l}\text { Job done } \\
\text { only women }\end{array}$ & $\begin{array}{l}0.094 \\
(0.305)\end{array}$ & $\begin{array}{l}-0.218 \\
(0.711)\end{array}$ & $\begin{array}{l}-0.284 \\
(0.906)\end{array}$ & $\begin{array}{l}0.349 \\
(1.149)\end{array}$ & $\begin{array}{l}0.380 \\
(1.220)\end{array}$ & $\begin{array}{l}0.198 \\
(0.633)\end{array}$ \\
\hline $\begin{array}{l}\text { formal } \\
\text { written } \\
\text { policy on } \\
\text { equal } \\
\text { opportunities }\end{array}$ & $\begin{array}{l}-0.101^{* *} \\
(2.494)\end{array}$ & $\begin{array}{l}-0.047 \\
(1.008)\end{array}$ & $\begin{array}{l}-0.059 \\
(1.372)\end{array}$ & $\begin{array}{l}-0.070 \\
(1.637)\end{array}$ & $\begin{array}{l}-0.076^{*} \\
(1.657)\end{array}$ & $\begin{array}{l}0.014 \\
(0.272)\end{array}$ \\
\hline $\begin{array}{l}\text { Flexible } \\
\text { working } \\
\text { hours }\end{array}$ & $\begin{array}{l}0.215^{* * *} \\
(8.580)\end{array}$ & $\begin{array}{l}0.100^{* * *} \\
(3.958)\end{array}$ & $\begin{array}{l}0.108 * * * \\
(4.279)\end{array}$ & $\begin{array}{l}0.194 * * * \\
(7.715)\end{array}$ & $\begin{array}{l}0.127 * * * \\
(4.864)\end{array}$ & $\begin{array}{l}0.152 * * * \\
(5.758)\end{array}$ \\
\hline Job Sharing & $\begin{array}{l}0.065 * * \\
(2.265)\end{array}$ & $\begin{array}{l}0.040 \\
(1.379)\end{array}$ & $\begin{array}{l}0.045 \\
(1.546)\end{array}$ & $\begin{array}{l}0.084^{* * *} \\
(2.907)\end{array}$ & $\begin{array}{l}0.013 \\
(0.439)\end{array}$ & $\begin{array}{l}0.022 \\
(0.726)\end{array}$ \\
\hline $\begin{array}{l}\text { Parental } \\
\text { leave }\end{array}$ & $\begin{array}{l}0.123 * * * \\
(4.906) \\
\end{array}$ & $\begin{array}{l}0.108^{* * *} \\
(4.302) \\
\end{array}$ & $\begin{array}{l}0.110^{* * *} \\
(4.382) \\
\end{array}$ & $\begin{array}{l}0.207 * * * \\
(8.273) \\
\end{array}$ & $\begin{array}{l}0.153^{* * *} \\
(5.947) \\
\end{array}$ & $\begin{array}{l}0.135^{* * *} \\
(5.246) \\
\end{array}$ \\
\hline $\begin{array}{l}\text { Working } \\
\text { from home }\end{array}$ & $\begin{array}{l}0.278^{* * *} \\
(6.440)\end{array}$ & $\begin{array}{l}0.123^{* * * *} \\
(2.835)\end{array}$ & $\begin{array}{l}0.265^{* * *} \\
(6.064)\end{array}$ & $\begin{array}{l}0.265^{* * *} \\
(6.117)\end{array}$ & $\begin{array}{l}0.188^{* * *} \\
(4.219)\end{array}$ & $\begin{array}{l}0.203^{* * *} \\
(4.535)\end{array}$ \\
\hline $\begin{array}{l}\text { Workplace } \\
\text { nursery or } \\
\text { help with the } \\
\text { cost of child } \\
\text { care }\end{array}$ & $\begin{array}{l}0.057 \\
(1.079)\end{array}$ & $\begin{array}{l}-0.065 \\
(1.180)\end{array}$ & $\begin{array}{l}-0.007 \\
(0.124)\end{array}$ & $\begin{array}{l}0.029 \\
(0.536)\end{array}$ & $\begin{array}{l}0.033 \\
(0.598)\end{array}$ & $\begin{array}{l}0.098^{*} \\
(1.703)\end{array}$ \\
\hline Constant & $\begin{array}{l}-2.196 * * * \\
(6.668)\end{array}$ & $\begin{array}{l}-2.415^{* * *} \\
(7.272)\end{array}$ & $\begin{array}{l}-2.121^{* * *} \\
(6.320)\end{array}$ & $\begin{array}{l}-1.643^{* * *} \\
(5.035)\end{array}$ & $\begin{array}{l}-2.029 * * * \\
(6.023)\end{array}$ & $\begin{array}{l}-2.143^{* * *} \\
(6.246)\end{array}$ \\
\hline Observations & 10348 & 10348 & 10348 & 10348 & 10348 & 10348 \\
\hline
\end{tabular}

Note: $\mathrm{t}$ stats in parenthesis

Other variables included are ethnic group, health, age marital status, children, educational qualifications, tenure, temporary/fixed term, hours, pay, size of organisation, industry, foreign ownership and collective bargaining coverage. 
Our results confirm many of the previous findings on job satisfaction. Long-standing health problems or disabilities, being divorced, higher qualifications, longer job tenures, lower weekly wages and trade union membership are all associated with lower satisfaction in all of the domains considered. Working in a job which is dominated by a single sex also has no significant impact on satisfaction, other things being equal. Adding flexible working practices to our specification does not significantly change the results. Flexible working hours, parental leave and the option of working from home all increase satisfaction in each of the domains; whilst job sharing increases satisfaction with the influence and respect but has no significant impact on satisfaction with pay or achievement. The presence of a workplace nursery or help with the cost of childcare only impacts on the pride satisfaction variable.

These results suggest therefore, that in these domains of job satisfaction women have no particular preference for different degrees of gender segregation. However, WERS does not contain a question on overall job satisfaction, and mean satisfaction in the six domains tends to be higher for women in jobs undertaken almost exclusively by women relative to women in less segregated jobs. In other words, the attributes of jobs in which women predominate are favourable to women in terms of women's preferences. 


\section{(b) BHPS Analysis}

The data used in this part of the analysis are drawn from the British Household Panel Survey (BHPS). The survey was first conducted in September 1991 and is carried out annually by the Institute for Social and Economic Research. The initial sample of approximately 5,500 households, 10,000 respondents was a nationally representative sample of households in 1991. All adults (16+) in the household are interviewed. As part of the survey individuals are asked how satisfied or dissatisfied they are with their present job overall on a scale of 1 to 7 , where 1 represents completely dissatisfied, 4 neither satisfied nor dissatisfied and 7 completely satisfied. Similar questions using the same scale were asked about total pay (including any overtime or bonuses), job security, hours of work and the actual work itself. In 1996, workers were also asked about the gender mix of employment in their job i.e. whether the individual's job is done almost exclusively by men, mainly by men, by a mixture of men and women, mainly by women or almost exclusively by women. Table 5 shows the average satisfaction rating by job mix. The figures suggest that men have lower job satisfaction when they work in jobs which are dominated by women. Women have higher job satisfaction when they work in female dominated jobs and have much lower satisfaction when they work in jobs which are predominantly carried out by men. $^{9}$

\footnotetext{
${ }^{9}$ Bender, Donohue and Heywood (2005) have analysed the relationship between job satisfaction and gender segregation for the USA. Confirming earlier studies women report higher overall job satisfaction than men and also higher job satisfaction in workplaces dominated by women workers. When they examine the cause of the latter relationship they find that it arises from a strong gender specific pattern of sorting based on 'the flexibility' of the job to accommodate family issues. Their US data include a wide range of questions designed to isolate the flexibility of each worker's job and the extent to which the demands of the job conflict with family responsibilities (not available in the BHPS). Women, but not men, obtain a large and highly significant increase in job satisfaction when they are employed in jobs that do not force them to choose between their jobs and family. The addition of the flexibility indicators increases the explanatory power of their model threefold, whilst making the gender composition variables insignificant. In short, this implies that the share of women employed per se has no impact on job satisfaction - what matters is the flexibility of the job.
} 
Table 5: Overall Job Satisfaction by Job Gender Mix

\begin{tabular}{|l|l|l|l|l|l|}
\hline & \multicolumn{3}{|l|}{ Job done... } \\
\hline $\begin{array}{l}\text { How satisfied are } \\
\text { you with your job } \\
\text { overall? }\end{array}$ & $\begin{array}{c}\text { Almost } \\
\text { exclusively by } \\
\text { men }\end{array}$ & $\begin{array}{l}\text { Mainly } \\
\text { by men }\end{array}$ & Equally & $\begin{array}{c}\text { Mainly by } \\
\text { women }\end{array}$ & $\begin{array}{c}\text { Almost } \\
\text { exclusively by } \\
\text { women }\end{array}$ \\
\hline Males & 5.25 & 5.28 & 5.26 & 5.19 & 5.17 \\
\hline Females & 4.67 & 5.50 & 5.50 & 5.48 & 5.70 \\
\hline
\end{tabular}

We extended this analysis using the ordered-probit approach detailed in section 4(a). When using this dataset we do not have a multi-level error term and thus we do not utilise the random effects variant of the estimator. The results of this estimation process are shown in table 6. Our main finding is that the gender mix of those performing a job has no effect on job satisfaction for men, whilst only the extreme case of working in job almost exclusively done by men, has a statistically significant (negative) impact on female job satisfaction. This supports the idea that it is the characteristics of female dominated jobs rather than the sex composition which determines overall job satisfaction. 
Table 6: Ordered Probit Analysis of Overall Job Satisfaction

\begin{tabular}{|l|l|l|l|}
\hline & $\begin{array}{l}\text { Males and } \\
\text { Females }\end{array}$ & Females & Males \\
\hline female & $0.110^{* *}$ & & \\
& $(2.261)$ & & \\
\hline Job done almost exclusively by men & -0.032 & $-0.879^{* * *}$ & 0.035 \\
& $(0.539)$ & $(3.573)$ & $(0.503)$ \\
\hline Job done or mainly by men & -0.004 & 0.018 & 0.005 \\
& $(0.067)$ & $(0.171)$ & $(0.071)$ \\
\hline Job done or mainly by women & -0.050 & -0.084 & 0.011 \\
& $(0.985)$ & $(1.434)$ & $(0.096)$ \\
\hline Job done almost exclusively by & $0.128^{* *}$ & 0.071 & -0.260 \\
women & $(2.037)$ & $(1.040)$ & $(0.770)$ \\
\hline Observations & 4012 & 2093 & 1919 \\
\hline
\end{tabular}

Other variables included in the model are age, educational qualifications, health, hours of work, earnings, job tenure, workplace size, permanent job, incremental pay systems, promotion opportunities, pay bonuses or profit share, manager, foreman/supervisor, travel to work time, regional dummies and industry dummies. 


\section{Occupational Choice and Gender Attitudes to Risk}

Using US data DeLeire and Levy (2004) have tested the proposition that individuals with strong aversion to risk will choose safer jobs. Further, they argue that workers who are raising children will be less willing to trade-on-the-job safety for wages, since their children depend on them; and this should especially be the case for single parents. Because married men with children are not in the role of primary care-giver, but married women with children are, the latter will be more risk averse than the former. Using econometric analysis they find that occupational choices are consistent with these propositions. In addition, there is an independent gender effect with the most safety orientated men having the same level of aversion to risk as the least safety-orientated group of women. In total these differences in risk aversion can explain no less than one quarter of the occupational segregation by gender in the USA.

It is possible to replicate the DeLeire and Levy analysis for the UK. First, we follow their descriptive analysis for two digit SOC occupations by calculating average fatality and injury rates for 2002/03 and 2003/4 based on HSE data for these years and LFS data for September - November 2004. Table 7 ranks occupations by their accident proneness and their employment of men and women. As figure 1 illustrates there is a negative relationship between the risk of death and the fraction of females employed. Further, this relationship is highly significant with a correlation coefficient of -0.794 , significant at a 99 per cent confidence limit (table 8 ). Figure 2 shows a similar relationship between risk of injury and fraction female $(r=-0641)$ again significant at a 99 per cent confidence level (table 9). The implication of this, though limited to only one dimension of occupational characteristics, is that we cannot rule 
out the possibility that occupational segregation by gender reflects in part gender preferences for particular types of work. This will exist even in the absence of any form of discrimination.

Following DeLeire and Levy we also estimate conditional logit models of occupational choice as a function of injury risk and other job attributes. Assume that the utility, a worker derives from a particular occupation, i, depends on that i worker's individual characteristics $\left(\mathrm{X}_{\mathrm{i}}\right)$ the wage offered $\mathrm{W}_{\mathrm{ij}}$, and the characteristics of the job $\mathrm{Z}_{\mathrm{j}}$, i.e.

$\mathrm{U}_{\mathrm{ij}}^{*}=\mathrm{u}\left(\mathrm{X}_{\mathrm{i}}, \mathrm{W}_{\mathrm{ij}}, \mathrm{Z}_{\mathrm{j}}\right)$

The wage a worker receives will be a function of the same individual and job characteristics as in (5), i.e.

$\mathrm{W}_{\mathrm{ij}}=\mathrm{F}\left(\mathrm{X}_{\mathrm{i}}, \mathrm{Z}_{\mathrm{j}}\right)$

Substituting equation (6) into equation (5) we obtain

$\mathrm{U}_{\mathrm{ij}}^{*}=\beta \mathrm{X}_{\mathrm{i}}+\alpha \mathrm{Z}_{\mathrm{j}}+\varepsilon_{\mathrm{ij}}$

Where $\varepsilon_{\mathrm{ij}}$ is a disturbance term. Hence the wage does not enter directly into the estimating equation. The independent variables include two accident variables, 18 job characteristics including physical strength and physical stamina derived from the Skills Survey (2001), and union coverage. With the exception of the accident and union variables each occupation (25 in all) is assigned the mean value for each variable obtained from workers' assessments of the importance of each attribute to their job. Separate equations are run for each sex, marital status group. The key results are contained in table 11 . Overall, women are found to be more risk averse than men. While the coefficient on the death rate for men is -260.9 for women it is - 
301.2. This shows that the death rate has a greater negative effect upon women's occupational choice, in relation to the degree of risk, than on that of men. Whilst the coefficient on the major injury variable is significant, but positive (as in DeLeire and Levy), for women it is negative (though insignificant $)^{10}$.

The distinction by family structure within gender is made because the fact that women choose safer jobs than men may not be due just to differences in preferences, but it could also be due to discrimination. Results of the conditional logit model show that married men are more risk averse than single men, whilst for women having children results in an aversion to occupations with a propensity to non-fatal injury as well as occupations with higher fatal injuries. Married women with children are more averse to risky occupations than married women with no children. Thus, in broad terms the DeLeire and Levy hypothesis appears to hold up for the UK. However, while DeLeire and Levy find that risk of death can explain 25 per cent of gender segregation in the US, we find that it can only explain about 5 per cent in Britain. This might reflect the fact that the accident rate is much higher in the US than it is in Britain.

\footnotetext{
${ }^{10}$ Risk of major injury and death are collinear with a correlation coefficient $r$ of 0.816 , significant at the 99 percent confidence level (table 10) and this explains the positive sign on log of major injury when the two risk variable are entered jointly.
} 
Table 7: Death Rates, Injury Rates and the Female Employment Concentration in Occupational Groups

\begin{tabular}{|c|c|c|c|}
\hline & $\begin{array}{c}\text { DEATH RATE } \\
\text { PER 100 } \\
\text { WORKERS }\end{array}$ & $\begin{array}{l}\text { MAJOR INJURY } \\
\text { RATE PER } 100 \\
\text { WORKERS }\end{array}$ & $\begin{array}{l}\text { FRACTION } \\
\text { FEMALE }\end{array}$ \\
\hline 51 skilled agricultural trades & 0.0204215 & 0.336546 & 0.074465 \\
\hline 53 skilled construction and building trades & 0.006881185 & 0.549184 & 0.010892 \\
\hline $\begin{array}{l}91 \text { elementary trades, plant and storage } \\
\text { related occupations }\end{array}$ & 0.003908387 & 0.366371 & 0.162832 \\
\hline $\begin{array}{l}82 \text { transport and mobile machine drivers } \\
\text { and operatives }\end{array}$ & 0.003278528 & 0.335542 & 0.033848 \\
\hline 81 process plant and machine operatives & 0.002975107 & 0.454165 & 0.241075 \\
\hline 52 skilled metal and electrical trades & 0.002080622 & 0.210947 & 0.014218 \\
\hline $\begin{array}{l}12 \text { managers and proprietors in agriculture } \\
\text { and services }\end{array}$ & 0.001598571 & 0.128685 & 0.426151 \\
\hline 21 science and technology professionals & 0.001004333 & 0.083123 & 0.152651 \\
\hline $\begin{array}{l}92 \text { elementary administration and service } \\
\text { occupations }\end{array}$ & 0.000560044 & 0.142601 & 0.581446 \\
\hline 33 protective service occupations & 0.000480361 & 0.312715 & 0.185253 \\
\hline $\begin{array}{l}31 \text { science and technology associate } \\
\text { professionals }\end{array}$ & 0.000435329 & 0.08478 & 0.227309 \\
\hline 54 textiles, printing and other skilled trades & 0.000319841 & 0.115676 & 0.335903 \\
\hline 34 culture, media and sports occupations & 0.000310276 & 0.043283 & 0.479544 \\
\hline 11 corporate managers & 0.000250183 & 0.034392 & 0.324647 \\
\hline $\begin{array}{l}62 \text { leisure and other personal service } \\
\text { occupations }\end{array}$ & 0.000238179 & 0.09813 & 0.629918 \\
\hline 61 caring personal service occupations & 0.00016649 & 0.099062 & 0.904776 \\
\hline $\begin{array}{l}24 \text { business and public service } \\
\text { professionals }\end{array}$ & 0.000145866 & 0.025891 & 0.416629 \\
\hline 71 sales occupations & $8.54606 \mathrm{E}-05$ & 0.089905 & 0.70318 \\
\hline 42 secretarial and related occupations & 5.70615E-05 & 0.023738 & 0.972832 \\
\hline 22 health professionals & 0 & 0.022133 & 0.491017 \\
\hline 72 customer service occupations & 0 & 0.058266 & 0.684553 \\
\hline $\begin{array}{l}32 \text { health and social welfare associate } \\
\text { professionals }\end{array}$ & 0 & 0.052311 & 0.830458 \\
\hline 23 teaching and research professionals & 0 & 0.051148 & 0.647242 \\
\hline 41 administrative occupations & 0 & 0.028674 & 0.747169 \\
\hline $\begin{array}{l}35 \text { business and public service associate } \\
\text { professionals }\end{array}$ & 0 & 0.017317 & 0.473469 \\
\hline
\end{tabular}


Figure 1: The Relationship between Risk of Death and Female Employment Concentration

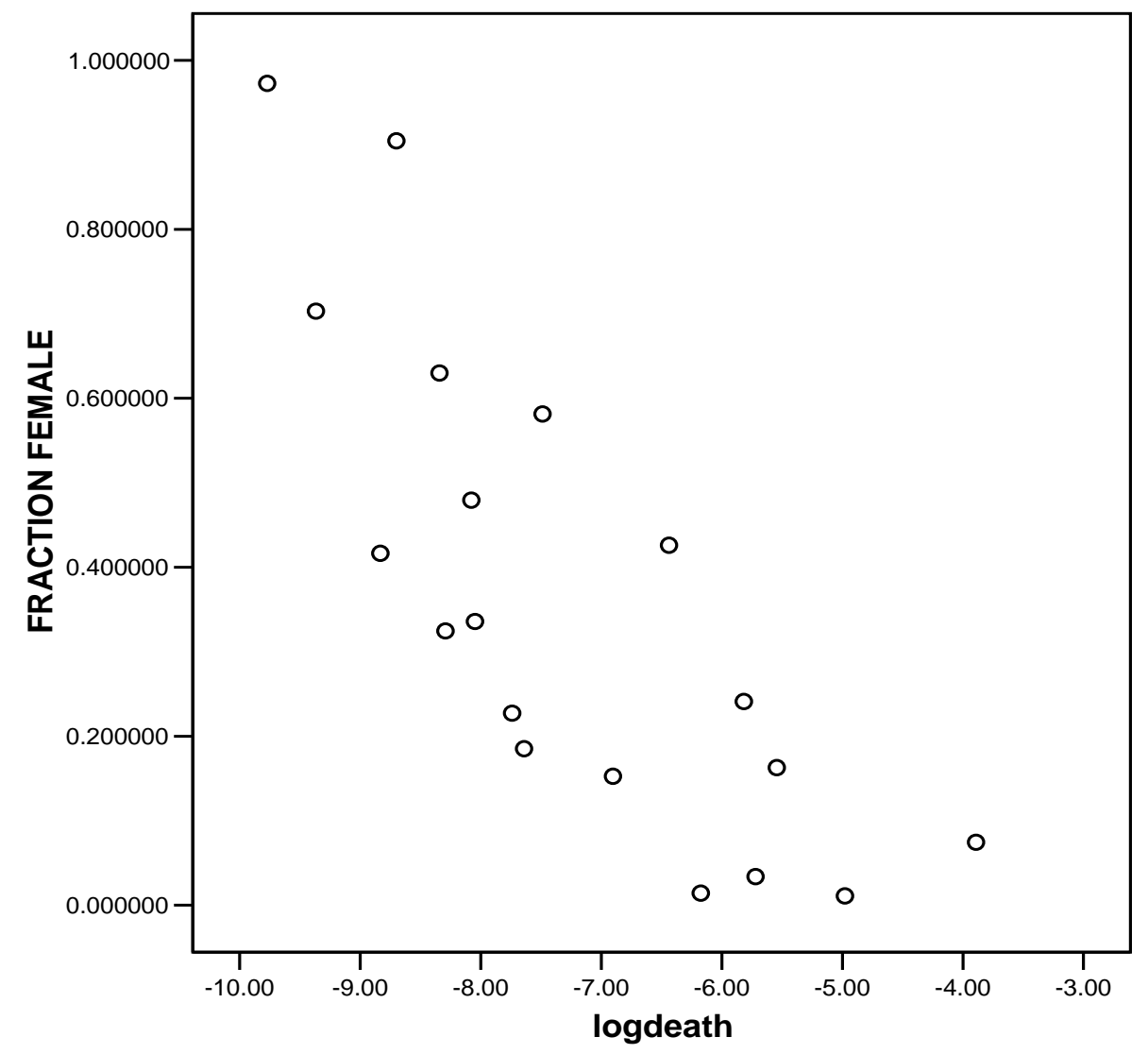

Table 8: The Correlation between Risk of Death and Female Employment Concentration

\begin{tabular}{|l|l|r|r|}
\hline & & $\begin{array}{c}\text { Log risk of } \\
\text { death }\end{array}$ & $\begin{array}{c}\text { FRACTION } \\
\text { FEMALE }\end{array}$ \\
\hline Log risk of death & Pearson Correlation & 1 & $-.794(* * *)$ \\
& Sig. (2-tailed) & 19 & .000 \\
& $\mathrm{~N}$ & $-.794(* *)$ & 19 \\
FRACTION FEMALE & Pearson Correlation & .000 & 1 \\
& Sig. (2-tailed) & 19 & 25 \\
& $\mathrm{~N}$ & & \\
\hline
\end{tabular}

** Correlation is significant at the 0.01 level (2-tailed). 
Figure 2: The Relationship between Risk of Major Injury and Female Employment Concentration

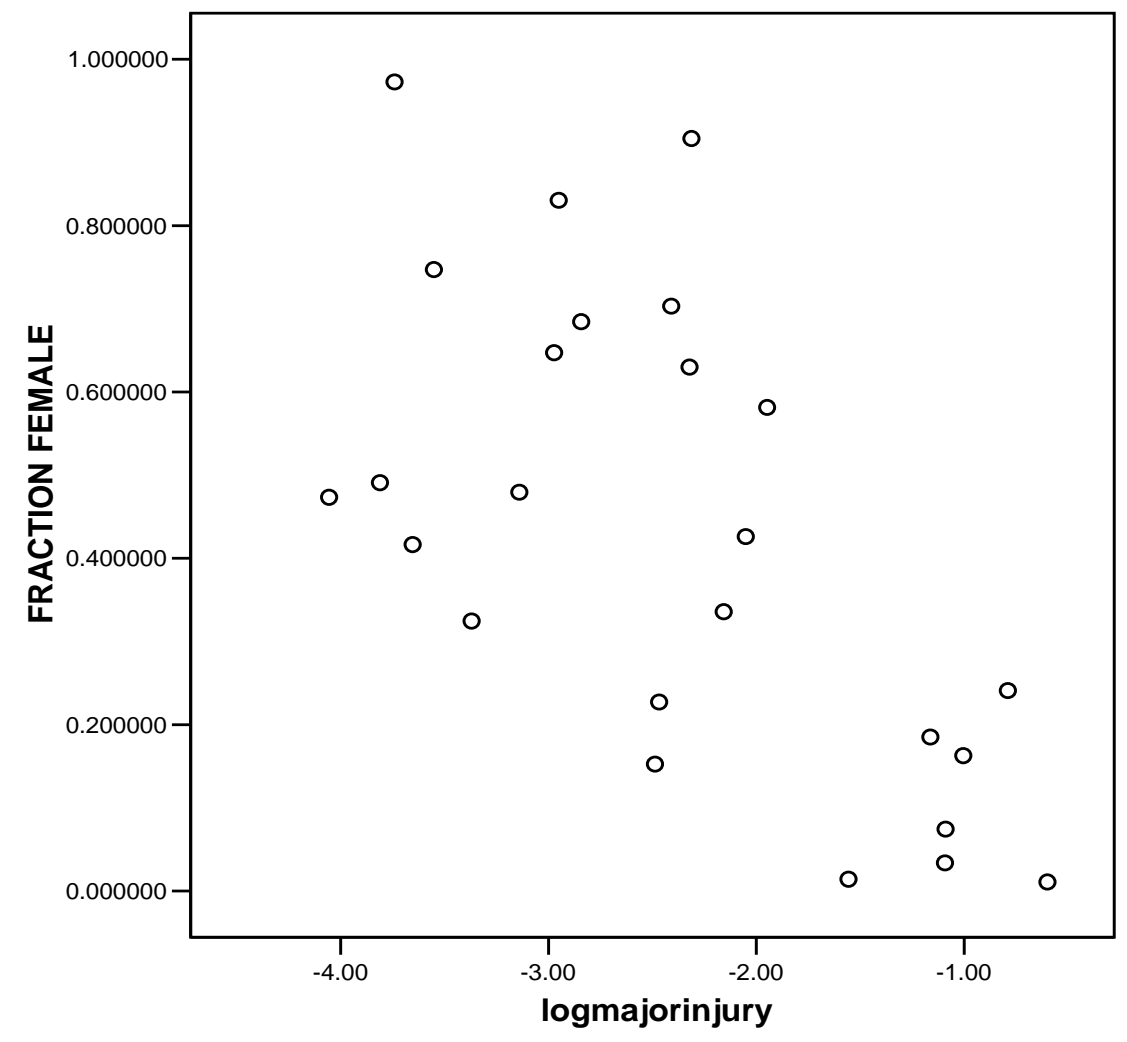

Table 9: The Correlation between Risk of Major Injury and Female Employment Concentration

\begin{tabular}{|l|l|r|r|}
\hline & & $\begin{array}{c}\text { FRACTION } \\
\text { FEMALE }\end{array}$ & $\begin{array}{c}\text { Log risk of } \\
\text { major injury }\end{array}$ \\
\hline FRACTION FEMALE & Pearson Correlation & 1 & $-.641(* * *)$ \\
& Sig. (2-tailed) & & .001 \\
& $\mathrm{~N}$ & 25 & 25 \\
Log risk of major injury & Pearson Correlation & $-.641\left({ }^{* * *}\right)$ & 1 \\
& Sig. (2-tailed) & .001 & 25 \\
& $\mathrm{~N}$ & 25 & 2 \\
\hline$* * *$ Correlation is significant at the 0.01 level (2-tailed).
\end{tabular}

Table 10: The Correlation between Risk of Death and Risk of Major Injury

\begin{tabular}{|l|l|r|r|}
\hline & & $\begin{array}{c}\text { Log risk of } \\
\text { major injury }\end{array}$ & $\begin{array}{c}\text { Log risk of } \\
\text { death }\end{array}$ \\
\hline $\begin{array}{l}\text { Log risk of major } \\
\text { injury }\end{array}$ & Pearson Correlation & 1 & $.816(* * *)$ \\
& Sig. (2-tailed) & & .000 \\
Log risk death & $\mathrm{N}$ & 25 & 19 \\
& Pearson Correlation & $.816(* * *)$ & 1 \\
& Sig. (2-tailed) & .000 & 19 \\
& $\mathrm{~N}$ & 19 & 19 \\
\hline
\end{tabular}

*** Correlation is significant at the 0.01 level (2-tailed). 
Table 11: Relationship between Accident Rates, Gender and Family Status

\begin{tabular}{|l|l|l|l|}
\hline & n & Risk of Death & Risk of Major Injury \\
\hline MEN & 620,175 & $-260.869^{* * *}$ & $\begin{array}{l}3.227^{* *} \\
(0.143)\end{array}$ \\
\hline Single men no children & 152,175 & -9.924 & 0.126 \\
& & $(7.620)$ & $(0.839)$ \\
\hline Single men with children & 75,050 & $-178.636^{* * *}$ & -1.240 \\
& & $(49.528)$ & $(1.010)$ \\
\hline Married men no children & 162,075 & $-269.856^{* * *}$ & $2.943^{* * *}$ \\
& & $(13.009)$ & $(0.248)$ \\
\hline Married men with children & 187,975 & $-311.093^{* * *}$ & $4.722^{* * *}$ \\
& & $(12.442)$ & $(0.265)$ \\
\hline SDW men no children & 43,000 & $-265.140^{* * *}$ & $4.175^{* * *}$ \\
& & $(25.351)$ & $(0.540)$ \\
\hline SDW men with children & 12,300 & $-430.189^{* * *}$ & $5.803^{* * *}$ \\
& & $(69.007)$ & $(1.095)$ \\
\hline WOMEN & 633,350 & $-301.210^{* * *}$ & -0.068 \\
& & $(25.581)$ & $(0.399)$ \\
\hline Single women no children & 125,275 & $-305.103^{* * *}$ & 0.782 \\
& & $(64.725)$ & $(0.929)$ \\
\hline Single women with children & 75,050 & $-162.393^{* * *}$ & $-1.786^{*}$ \\
& & $(48.979)$ & $(1.016)$ \\
\hline Married women no children & 166,500 & $-230.049^{* * *}$ & -1.018 \\
& & $(30.637)$ & $(0.701)$ \\
\hline Married women with children & 168,450 & $-1309.128^{* * *}$ & $10.506^{* * *}$ \\
& & $(158.146)$ & $(1.811)$ \\
\hline SDW women no children & 55,625 & $-1414.684^{* * *}$ & $12.846^{* * *}$ \\
& & $(237.526)$ & $(2.713)$ \\
\hline SDW women with children & 40,025 & $-188.124^{* * *}$ & -1.377 \\
& & $(46.517)$ & $(1.290)$ \\
\hline
\end{tabular}

Standard errors in parenthesis 


\section{Self-Employment and Segregation}

The incidence of self employment is much higher for men than for women. Thus the Quarterly Labour Force Survey, December 2004 to February 2005, gives a self employment rate of 17.3 per cent for men and 7.3 per cent for women. As a test of the hypothesis that women are forced into certain occupations by employers we compare the segregation indices for individuals who work for employers with the indices for those who are self employed, the intuition being that occupational choices for those who are self-employed are not governed by employer practices. We construct our indices using data from the British Household panel survey. We restrict our sample to individuals of working age. Table 12 below shows that in each year considered, segregation is higher amongst self-employed workers than employees, regardless of the measure of segregation used. Further, over the period considered, unlike the case of employee segregation, occupational segregation by gender has actually been increasing according to the ID measure and this is confirmed by the KM measure.

Table 12: Segregation Measures using the BHPS

\begin{tabular}{|l|l|l|l|l|}
\hline & \multicolumn{2}{l}{$\begin{array}{l}\text { Index of Dissimilarity Between } \\
\text { Occupations }\end{array}$} & \multicolumn{2}{l|}{ Karmel and Maclachlan Index } \\
\hline Year & Self Employed & Employed & $\begin{array}{l}\text { Self } \\
\text { Employed }\end{array}$ & Employed \\
\hline 1991 & 0.397 & 0.378 & 0.297 & 0.255 \\
\hline 1992 & 0.393 & 0.358 & 0.299 & 0.255 \\
\hline 1993 & 0.393 & 0.359 & 0.309 & 0.257 \\
\hline 1994 & 0.389 & 0.357 & 0.304 & 0.260 \\
\hline 1995 & 0.413 & 0.362 & 0.305 & 0.258 \\
\hline 1966 & 0.410 & 0.345 & 0.307 & 0.259 \\
\hline 1997 & 0.396 & 0.373 & 0.291 & 0.234 \\
\hline 1998 & 0.412 & 0.359 & 0.320 & 0.259 \\
\hline 1999 & 0.380 & 0.354 & 0.325 & 0.262 \\
\hline 2000 & 0.357 & 0.346 & 0.314 & 0.263 \\
\hline 2001 & 0.374 & 0.344 & 0.315 & 0.265 \\
\hline 2002 & 0.401 & 0.350 & 0.318 & 0.266 \\
\hline
\end{tabular}

We confirm this by using data from the latest Labour Force Survey (Spring 2005) (Table 13). Again, we restrict our sample to individuals of working age. We find that irrespective of the measure used, there is less occupational segregation between employed workers than self employed workers. 
Table 13: Segregation Measures using the LFS

\begin{tabular}{|l|l|l|l|l|}
\hline & \multicolumn{2}{|l|}{$\begin{array}{l}\text { Index of Dissimilarity Between } \\
\text { Occupations }\end{array}$} & $\begin{array}{l}\text { Karmel and Maclachlan } \\
\text { Index }\end{array}$ \\
\hline & Self Employed & Employed & $\begin{array}{l}\text { Self } \\
\text { Employed }\end{array}$ & Employed \\
\hline & .549 & .521 & .2713 & .2647 \\
\hline $\begin{array}{l}\text { Number of } \\
\text { observations }\end{array}$ & 6689 & 47643 & 6689 & 47643 \\
\hline
\end{tabular}

The fact that not only are women less likely to become self-employed than are men and when they do so are likely to choose different occupations is consistent with gender differences in preferences for particular types of work. 


\section{Conclusions}

Our analysis of job satisfaction in relation to gender composition and occupational choice based on relative risk aversion and self employment points to preferences for particular types of work being different for men and women. In turn, this suggests that some degree of gender segregation is optimal for both men and women and any attempt to enforce an equal distribution of men and women across occupations through affirmative action or other means is undesirable. That is not to say that the current degree of gender segregation is optimal, but we simply do not know what that degree might be, as we have focused only on three aspects of job preferences in this paper. We have also ignored possible effects on the efficiency of production, though in this respect theoretical models yield ambiguous predictions. ${ }^{11}$ Legislation should, therefore, be focused on preventing employers from discriminating against a minority of women who may prefer to obtain jobs in male dominated areas rather than attempting to engineer social change by equalising the proportions of men and women across occupations.

\footnotetext{
${ }^{11}$ See, for example Holzer and Neumark (2000) page 522. It is possible to assess the impact of affirmative action by considering the case of California, where proposition 209 ended the State's affirmative action programme in 1997. Myers (2005) found that employment among women and minorities dropped sharply through a decline in participation as opposed to an increase in unemployment. It is suggested that either such programmes in California were inefficient or that they failed to create lasting change in prejudicial attitudes.
} 


\section{References}

Arabsheibani, G., de Meza D., Maloney J., and Pearson B.,

And A Vision Appeared unto Them of a Great Profit: Evidence of Self-deception among the Self-employed, Economics Letters, Vol. 67, 2000, pp 35-41

Belfield, C R.,

"Workforce gender effects on firm performance and workers' pay: evidence for the UK",

Applied Economics, vol. 37, no. 8, May, 2005, pp. 885-891

Bender K.A., Donohue M. and Heywood J.S., Job Satisfaction and Gender Segregation,

Oxford Economic Papers, Vol. 57, No. 3, July, 2005, pp. 479-496

Brown S. and Taylor K.

Wage Growth, Human Capital and Risk Preference: Evidence from the British Household Panel, Manchester School, Vol. 73(6), 2005, pp 688-709

Bryan, M.L.,

Analysing Working Time: Why use Linked Employer-Employee Data, Institute for Economic Research (ISER), University of Essex, September, 2005

Datta Gupta N., Poulsen A. and Villeval M.C.

Male and Female Competitive Behavior; Experimental Evidence, IZA Discussion Paper No. 1833, November, 2005.

DeLeire T. and Levy H.,

Worker Sorting and the Risk of Death on the Job,

Journal of Labor Economics, Vol. 22, No. 4, 2004, pp. 925-953

Duncan O.D. and Duncan B.,

A Methodological Analysis of Segregation Indices,

American Sociological Review, Vol. 20, 1955, pp. 210-217

Ekelund J., Johansson F., Jarvelin, M.R. and Lichtermann, D.

Self Employment and Risk Aversion: Evidence from Psychological Test Data, Labour Economics, Vol. 12, No. 5, October, 2005 pp 649-659

Elliot, J.,

Comparing Occupational Segregation in Great Britain and the United States: The benefits of using a multi-group measure of segregation,"

Work, Employment and Society Vol. 19, No.1, March 2005, pp. 153-174.

EOC,

Equal Pay Task Force: Just Pay, Manchester, 2001

EOC,

Free to Choose: Tackling Gender Barriers to Better Jobs, Manchester, 2005 
Holzer H. and Neumark D.,

Assessing Affirmative Action, Journal of Economics Literature, Vol. XXXVIII, September, 2000, pp. 483-568

Karmel T. and Maclachlan M.,

Occupational Sex Segregation: Increasing or Decreasing?, Economic Record, Vol. 64, 1988, pp. 187-195

Kidd, M. and Goninon, T.,

Female Concentration and the Gender Wage Differential in the United Kingdom Applied Economics Letters, vol. 7(5), 2000, pp 337-40.

Myers C.K.

A Cure for Discrimination? Affirmative Action and the Case of California's Proposition 209, IZA Discussion Paper No. 1674, July, 2005-11-16

Polachik S.W. and Xiang J.,

The Effects of Incomplete Employee Wage Information: A Cross Country Analysis, IZA Discussion Paper No. 1735, September, 2005.

Scotchmer, S.,

Affirmative Action in Hierarchies, NBER Working Paper 11213, Cambridge, Mass., March 2005 


\section{Self-Employment and Segregation}

As a test the hypothesis that women are forced into certain occupations by employers we compare the segregation indices for individuals who work for employer with the indices for those who are self employed. The intuition being that occupational choices for those who are self-employed are not governed by employer practices. We construct our indices using data from the British Household panel survey. We restrict our sample to individuals of working age. Table 12 below show that in each year considered, segregation is higher amongst self-employed workers than employees, regardless of the measure of the segregation used.

Table 12: Segregation Measures using the BHPS

\begin{tabular}{|l|l|l|l|l|}
\hline & \multicolumn{2}{l|}{$\begin{array}{l}\text { Index of Dissimilarity Between } \\
\text { Occupations }\end{array}$} & \multicolumn{2}{l|}{ Karmel and Maclachlan Index } \\
\hline Year & Self Employed & Employed & $\begin{array}{l}\text { Self } \\
\text { Employed }\end{array}$ & Employed \\
\hline 1991 & 0.397 & 0.378 & 0.297 & 0.255 \\
\hline 1992 & 0.393 & 0.358 & 0.299 & 0.255 \\
\hline 1993 & 0.393 & 0.359 & 0.309 & 0.257 \\
\hline 1994 & 0.389 & 0.357 & 0.304 & 0.260 \\
\hline 1995 & 0.413 & 0.362 & 0.305 & 0.258 \\
\hline 1966 & 0.410 & 0.345 & 0.307 & 0.259 \\
\hline 1997 & 0.396 & 0.373 & 0.291 & 0.234 \\
\hline 1998 & 0.412 & 0.359 & 0.320 & 0.259 \\
\hline 1999 & 0.380 & 0.354 & 0.325 & 0.262 \\
\hline 2000 & 0.357 & 0.346 & 0.314 & 0.263 \\
\hline 2001 & 0.374 & 0.344 & 0.315 & 0.265 \\
\hline 2002 & 0.401 & 0.350 & 0.318 & 0.266 \\
\hline
\end{tabular}

We confirm this by using data from the latest labour force survey (Spring 2005) (Table 13). Again, we restrict our sample to individuals of working age. We find that irrespective of the measure used, there is less occupation segregation between employed workers than self employed workers.

Table 13: Segregation Measures using the LFS

\begin{tabular}{|l|l|l|l|l|}
\hline \multicolumn{4}{|l|}{$\begin{array}{l}\text { Index of Dissimilarity Between } \\
\text { Occupations }\end{array}$} & $\begin{array}{l}\text { Karmel and Maclachlan } \\
\text { Index }\end{array}$ \\
\hline & Self Employed & Employed & $\begin{array}{l}\text { Self } \\
\text { Employed }\end{array}$ & Employed \\
\hline & .549 & .521 & .2713 & .2647 \\
\hline $\begin{array}{l}\text { Number of } \\
\text { observations }\end{array}$ & 6689 & 47643 & 6689 & 47643 \\
\hline
\end{tabular}

Again segregation is higher amongst self employed workers than employees. 


\section{Conclusions}

Our analysis of job satisfaction in relation to gender composition and occupational choice based on relative risk aversion points to preferences for particular types of work being different for men and women. In turn, this suggests that some degree of gender segregation is optimal for both men and women and any attempt to enforce an equal distribution of men and women across occupations through affirmative action or other means is undesirable. That is not to say that the current degree of gender segregation is optimal, but we simply do not know what that degree might be optimal, as we have focused only on three aspects of job preferences in this paper. We have also ignored possible effects on the efficiency of production, though in this respect theoretical models yield ambiguous predictions. ${ }^{12}$

\footnotetext{
${ }^{12}$ See, for example Holzer and Neumark (2000) page 522.
} 


\section{References}

Belfield, C R.,

"Workforce gender effects on firm performance and workers' pay: evidence for the UK",

Applied Economics, vol. 37, no. 8, May, 2005, pp. 885-891

Bender K.A., Donohue M. and Heywood J.S., Job Satisfaction and Gender Segregation,

Oxford Economic Papers, Vol. 57, No. 3, July, 2005, pp. 479-496

Brown S. and Taylor K.

Wage Growth, Human Capital and Risk Preference: Evidence from the British Household Panel, Manchester School, Vol. 73(6), 2005, pp 688-709

Bryan, M.L.,

Analysing Working Time: Why use Linked Employer-Employee Data, Institute for Economic Research (ISER), University of Essex, September, 2005

Datta Gupta N., Poulsen A. and Villeval M.C.

Male and Female Competitive Behavior; Experimental Evidence, IZA Discussion Paper No. 1833, November, 2005.

DeLeire T. and Levy H.,

Worker Sorting and the Risk of Death on the Job,

Journal of Labor Economics, Vol. 22, No. 4, 2004, pp. 925-953

Duncan O.D. and Duncan B.,

A Methodological Analysis of Segregation Indices,

American Sociological Review, Vol. 20, 1955, pp. 210-217

Ebelund J., Johanssou F., Javelin, M.R. and Lichtermann, D.

Self Employment and Risk Aversion: Evidence from Psychological Test Data, Labour Economics, Vol. 12, No. 5, October, 2005 pp 649-659

Elliot, J.,

Comparing Occupational Segregation in Great Britain and the United States: The benefits of using a multi-group measure of segregation,"

Work, Employment and Society Vol. 19, No.1, March 2005, pp. 153-174.

EOC,

Equal Pay Task Force: Just Pay, Manchester, 2001

EOC,

Free to Choose: Tackling Gender Barriers to Better Jobs, Manchester, 2005

Holzer H. and Neumark D.,

Assessing Affirmative Action, Journal of Economics Literature, Vol. XXXVIII, September, 2000, pp. 483-568

Karmel T. and Maclachlan M., 
Occupational Sex Segregation: Increasing or Decreasing?, Economic Record, Vol. 64, 1988, pp. 187-195

Kidd, M. and Goninon, T.,

Female Concentration and the Gender Wage Differential in the United Kingdom Applied Economics Letters, vol. 7(5), 2000, pp 337-40.

Myers C.K.

A Cure for Discrimination? Affirmative Actions and the Case of Califormic Proposition 209, IZA Discussion Paper No. 1674, July, 2005-11-16

Polachik S.W. and Xiang J.,

The Effects of Incomplete Employee Wage Information: A Cross Country Analysis, IZA Discussion Paper No. 1735, September, 2005.

Scotchmer, S.,

Affirmative Action in Hierarchies, NBER Working Paper 11213, Cambridge, Mass., March 2005 